\title{
The Effect of Cooperative Learning Model Type Two Stay Two Stray and Learning Style on Social Sciences Learning Outcomes of Grade IV Elementary School Students
}

\author{
Wachid Yuli Irfanto ${ }^{1, a^{*}}$, Mustaji ${ }^{1, b}$, and Muhammad Jacky $y^{1, c}$ \\ ${ }_{1}^{1}$ Postgraduate Basic Education, Surabaya State University, Indonesia \\ wachidghadite@gmail.com \\ ${ }^{*}$ Corresponding Author \\ Whatsapp number: [085748712010]
}

How to Cite : Iffanto, W., Y., Mustaji, M., \& Jacky, M. (2019). The Effect of Cooperative Learning Model Type Two Stay Two Stray and Learning Style on Social Sciences Learning Outcomes of Grade IV Elementary School Students. International Journal for Educational and Vocational Studies, 1 (3), 212-216.

\section{ARTICLE HISTORY \\ Received:3 April 2019 \\ Revised: 20 May2019 \\ Accepted: 21 July 2019 \\ KEYWORDS \\ Cooperative Learning Model, \\ Two Stay Two Stray, \\ Learning Style, \\ Learning Outcomes}

\begin{abstract}
This study aims to determine the existence of significant differences in students who carry out learning using the two stay two stray model and learning styles towards learning outcomes. The design used in this study is the Pre-Experimental Design design of the One-Group Pretest-Posttest Design. The technique of data analysis using validity and reliability tests. The average results of the pretest and posttest values obtained in the research subjects (class IV) showed that there was an increase before the treatment and after treatment, both students who had the type of visual learning style, audiovisual and kinesthetic. In the type of visual learning style, the pretest score was 65.24 while the posttest score was 79.17 . For the type of audio-visual learning style, the pretest score was 66.74 , while the posttest score was 82.26 and for the last type, the kinesthetic learning style obtained a pretest score of 67.32 while the posttest score was 84.75 . All types of student learning styles experience increased learning outcomes when given treatment with model two stay two strays. So from that shows that the learning model of two stay two stray with visual learning style, audiovisual and kinesthetic experiences a significant increase in improving student learning outcomes.
\end{abstract}

This is an open access article under the CC-BY-SA license.

\section{INTRODUCTION}

In the era of globalization, the development of a nation is very much determined by the human resources available to the nation. Improving the quality of human resources from an early age is an important thing that must be seriously considered. To be able to improve the quality of human resources, quality education is also needed. The advancement and retreat of a nation is dependent on the progress or decline of education in the nation. Therefore, education is the main thing that must be obtained by everyone.

Education has an important role in preparing quality human resources. Through education, the ideals of a nation can be realized to the younger generation, especially for those who still have formal education in schools. In the implementation of formal education in schools, it is inseparable from the presence of an educator, namely a teacher and an educated person, namely students. Tilaar (2002: 435) states that "the essence of education is humanize humans, namely a process that sees humans as a whole in existence".

Education is one of the factors that influence the quality of life of a nation. Muhammad Saroni (2011:10) that, "education is a process which takes place in life as an effort to balance conditions in oneself with external conditions. This balancing process is a form of survival that is done so that you can follow each activities that take place in life".

The role of education is very important to create a smart, peaceful, open and democratic life. Updates in the field of education should always be done in order to achieve the desired goals. This renewal of education is certainly carried out at all levels of education, especially in Elementary Schools (SD). Primary school education is the initial stage in the national education level. According to Herbison and Myers (Panpan Achmad Fadjri, 2000: 36) "Human resource development means the need for improvement knowledge, skills of the abilities of everyone in a person community ". This is where the initial concepts of knowledge will be built in various subjects. 
Education is one of the factors that influence the quality of life of a nation. The role of education is very important to create a smart, peaceful, open and democratic life. Updates in the field of education should always be done in order to achieve the desired goals. This renewal of education is certainly carried out at all levels of education, especially in Elementary Schools (SD). Primary school education is the initial stage in the national education level. This is where the initial concepts of knowledge will be built in various subjects. Todaro \& Smith (2003: 404) states that "education plays a key role in shaping human ability to absorb modern technology, and to develop agar capacity creating sustainable growth and development".

One of the subjects in elementary school is Social Sciences (IPS). IPS is one of the subjects that examines a set of events, facts, concepts, and generalizations. related to social issues. Contains geography, history, sociology and economics. Through social studies subjects, students are directed to be democratic, responsible citizens and peaceful citizens of the world (Ahmadi and Amri, 2014: 10).

According to Sapriya (2011: 12) IPS at the elementary level basically aims to prepare students as citizens who master knowledge, skills, attitudes and values that can be used as the ability to solve problems personal or social problems as well as the ability to make decisions and participate in various community activities in order to become good citizens. These goals can be achieved if the teacher is creative in designing learning that can be fun and liked by students.

In designing social studies learning, teachers must design learning activities by choosing learning models that can activate students, provide varied learning resources, so that it is easy for students to absorb information and be able to improve learning outcomes. Learning outcomes are the most important part of learning. Sudjana (2009: 3) defines student learning outcomes in essence is changes in behavior as a result of learning in a broader sense covering the fields of cognitive, affective, and psychomotor. Learning outcomes can be seen through evaluation activities that aim to obtain evidence data that will show the level of students' ability to achieve learning goals.

But the fact that up to now is that there are still many teachers who still apply conventional learning models, especially in social studies learning. There are still weaknesses in the implementation of the social studies education learning process. Some of the weaknesses in this conventional learning model include, the teacher does not include students in the learning process, but the teacher is more likely to use lectures that only require students on the strength of memory and memorization of events and the names of characters, without developing thinking insights and problem solving allows students to learn actively (Susanto, 2014: 3).

Based on observations on Wednesday, November 14, 2018 in the fourth grade of SDN Hulaan, it can be seen that during the social studies learning activities the teacher delivered material based on textbooks only. Learning is still teacher-centered so learning activities become less effective because students become passive because they only hear information from the teacher, students are less enthusiastic in taking lessons, there are still students who play alone, students do not pay attention to teacher explanations even though they are in the classroom, and students interfere friends who are watching the teacher. Based on the results of the documentation, it is known that the score of 18 Social Sciences subjects from 48 students in the daily test scores below the Minimum Completion Criteria (KKM) of the fourth grade IPS subjects that have been set at 75 . Such conditions must be addressed immediately.

Based on these problems, the teacher must be able to design learning using a more effective learning model and more emphasis on student learning activeness in learning activities. One possible learning model that can be applied to social studies is the learning model of two stay two stray (TSTS). The two stay two stray (TSTS) learning model is a group learning model that gives groups the opportunity to share results and information with other groups (Komalasari, 2014: 69). This learning model is widely used to realize student-centered teaching and learning activities. The use of this learning model will direct students to be active, both in discussion, question and answer, looking for answers, explaining and listening to the material explained by his friend.

The advantages of the learning model of two stay two stray (TSTS), namely, each student is motivated to master the material, eliminate the gap between the smart and not smart, encourage students to appear excellent because they bring the good name of the group, and create a happy atmosphere in learning. Thus even though during the last hours of study, students are still enthusiastic about learning (Kurniasih and Sani, 2016: 76). Therefore, this learning model can foster an attitude of cooperation, motivation and active learning of students, so that it will have an impact on the learning outcomes.

Other factors that need to be considered from a student that comes from within the learners (internal factors), one of these internal factors that can affect student learning outcomes, namely learning styles. Learning style is a consistent way done by a student in capturing stimulus or information, how to remember, think and solve problems (Nasution, 2008: 94). Each student has their own way of absorbing the learning delivered by the teacher. Teachers need to pay attention to the differences that exist in students, this is one of the ways teachers get closer to students.

The characteristics of the different students made a difference in the students' understanding of the material presented by the teacher. Therefore, the teacher has a heavy duty in carrying out learning, because each teacher must know the characteristics of each student, in this way it will be easier for the teacher to carry out teaching and learning activities in the classroom.

The learning styles of the students in general outline 
there are 3, namely the Visual, Auditory and Kinesthetic learning styles. The three types of learning styles in these students have different ways and approaches according to the characteristics possessed by students. Similar to the subject of Social Sciences, the type of learning style of students in capturing knowledge from the teacher also varies according to the ability of students to process Social Sciences material that is quite extensive and numerous.

There are several types of learning styles that are owned by students. This is in accordance with the characteristics of students who are different from one another. Learning styles can be classified into three namely visual learning styles, auditory learning styles, and kinesthetic learning styles. 1) visual learning style explains that a person learning style must first look at the evidence to then be able to believe it, for example through illustrations of images, videos, etc.; 2) Furthermore, the auditory learning style is a learning style that relies on hearing to be able to understand and believe it; 3) kinesthetic learning style is a learning style in which a person utilizes certain parts of his physical as an optimal learning tool can be classified as someone who has a kinesthetic learning style.

Based on he explanation above, it can be concluded that learning styles are very important when a person lives somewhere. When students already know the learning style, it will make it easier for these students to take part in learning activities, so that learners will be easier to learn and faster to succeed in accepting the learning process. Identifying students' learning styles, teachers can benefit in carrying out learning, namely students will be easier and more effective in solving problems faced. When students have been able to solve a problem faced, it will make students more control themselves in their life habits to reduce errors in solving problems.

Based on the description above, the researcher will carry out development research with the title "The Influence of Cooperative Learning Type Two Stay Two Stray and Learning Styles Against Social Sciences Learning Outcomes of Grade IV Elementary School Students".

\section{METHODS}

Research designed by researchers is to use experimental methods. The research design used in this study is the Pre-Experimental Design design of the One-Group Pretest-Posttest Design. In this design there is only one class group that has been determined. This design is described as follows:

Tabel 1. One-Group Pretest-Posttest Design.

\begin{tabular}{lll}
\hline $\mathrm{O}_{1}$ & $\mathrm{X}$ & $\mathrm{O}_{2}$ \\
\hline
\end{tabular}

Figure 1. Research Design

(Source: Sugiyono, 2010: 112)
Information:

$\mathrm{O}_{1} \quad$ : Results of the pretest

$\mathrm{O}_{2} \quad$ : Posttest results

X : Treatment using model two stay two stray

This research was conducted at SDN Hulaan Gresik in even semester 2018/2019 academic year. The choice of location is based on the following considerations: (1) the problems of social studies learning outcomes of students in grade IV of SDN Hulaan Gresik. (2) the willingness of the school to cooperate in research activities; ) There are no studies with similar titles in this school. The sample in this study was fourth grade students of SDN Hulaan Gresik in the academic year 2018/2019 which consisted of 1 class with 36 students.

In this study there are three variables, namely the independent variable (independent) the moderator variable and the dependent variable (dependent). The independent variable in this study is the cooperative learning model type two stay two stray, for the moderator variable is the learning style, while the dependent variable is the learning outcome.

The data collection technique in this study is to use test methods and questionnaires. The questionnaire used in this study is the student learning style questionnaire. The questionnaire of learning styles is used to determine the differences in student learning styles towards Social Sciences subjects. The various learning styles used are visual learners, auditory learners, and kinestetic learners. This instrument is measured using the Guttman scale which is clear and consistent with the problem being asked. On the Guttman scale there are only 2 intervals, namely the Yes and No or True and False answers, so that you get clear answers about the classification of learning styles. This test is used to determine the level of student learning outcomes or measure skills, knowledge, attitudes, intelligence, abilities, which are owned by an individual in following the learning before and after using the two stay two stray model. Before the instrument is used to retrieve data, the instrument needs to be tested on students. After that, the validity test and reliability test were carried out.

\section{RESULTS AND DISCUSSION}

The results of the study are two stay two stray models and learning styles towards learning outcomes. Questionnaire given to students is to find out the learning styles that exist in students towards learning outcomes achieved. As well as the tests given in the form of multiple choice test questions as many as 20 questions. The test was used in the research subject group in the form of pretest and posttest. The following are groups of learning styles that exist in students in learning and the average results of pretest and posttest. 
Tabel 2. Student Learning Style Questionnaire Analysis Results

\begin{tabular}{cc}
\hline Learning Style & Details \\
\hline Visual & 12 \\
\hline Audiovisual & 8 \\
\hline Kenesthetic & 16 \\
\hline Total & 36 \\
\hline
\end{tabular}

Based on table 2 shows that the results of the learning style questionnaire analysis in the research subject group above shows that there are differences in learning styles that each student has. This shows how students capture lessons with different learning styles. The following are the results of the pretest and posttest scores based on student learning styles.

Tabel 3. Value Pretest dan Posttest Based on Learning Style

\begin{tabular}{|c|c|c|c|c|}
\hline \multirow{6}{*}{$\begin{array}{l}\text { Research } \\
\text { Subject } \\
\text { (Class IV) }\end{array}$} & \multirow{3}{*}{$\begin{array}{l}\text { Types of } \\
\text { Learning } \\
\text { Styles }\end{array}$} & \multicolumn{3}{|c|}{ Average } \\
\hline & & & \multirow{5}{*}{$\begin{array}{l}\text { Treatment } \\
\text { (Two Stay } \\
\text { Two Stray } \\
\text { Learning } \\
\text { Model) }\end{array}$} & \\
\hline & & Pretest & & Postest \\
\hline & Visual & 68,83 & & 81,25 \\
\hline & Audio Visual & 68,94 & & 82,89 \\
\hline & Kinesthetic & 69,32 & & 83,68 \\
\hline
\end{tabular}

Based on table 3 shows that the average results of the pretest and posttest scores obtained by the research subjects (class IV) showed that there was an increase before the treatment and after treatment, both students who had the type of visual, audio-visual and kinesthetic learning styles. In the type of visual learning style, the pretest score was 65.24 while the posttest score was 79.17. For the type of audio-visual learning style, the pretest score was 66.74 , while the posttest score was 82.26 and for the last type the kinesthetic learning style obtained a pretest score of 67.32 while the posttest score was 84.75. All types of student learning styles experience increased learning outcomes when given treatment with model two stay two stray.

Because the average value of the posttest results is higher than the average value of the pretest results, it can be concluded that student learning outcomes based on the type of learning style given treatment using the two stay two stray learning model is better than learning that is not treated.

\section{CONCLUSION}

Based on the results of the research described above, it can be concluded that there are differences between before being given treatment using the two stay two stray model and the learning style with after being treated using the model two stay two stray and learning styles.

So, learning using the two stay two stray models and learning styles can improve the ability of student learning outcomes in a learning activity. This is relevant to the research conducted by Ludi Wishnu Wardana, Ratna Setyani and Gleydis Harwida (2018). As well as Ita Afrie Lusiana, Punaji Setyosari, and Budi Eko Soetjipto (2016) that the learning model of two stay two stray can improve students' cognitive learning outcomes in Social Sciences subjects.

\section{REFERENCES}

Ahmadi \& Amri Sofyan. 2014. Pengembangan Bahan Ajar dan Model Pembelajaran. Tematik Integratif. Jakarta: PT. Prestasi Pustakaraya.

Cahya Septimarmisa, Syamsurizal, Lufri (2018). "The Influence of two Stay Two Stray Learning Model Nuanced by Scientific Literacy on Students' Learning Competence in SMPN 4 KERINCI' International Journal of Progressive Sciences and Technologies. Vol. 8 No. 1 April 2018.

Ita Afrie Lusiana, Punaji Setyosari, Budi Eko Soetjipto (2017). "The Application of TwoStay Two Stray (TSTS) and Fan-N-Pick Learning Models to Improve Students' Motivation and Learning Outcomes on Social studies Subject" International Journal of Academic Research in Progressive Education and Development. Vol. 6, No. 3. 2017.

Komalasari. (2014). Pembelajaran kontekstual konsep dan aplikasi. Bandung: Refika Aditama.

Kurniasih, Imas dan Berlin Sani. 2016. Ragam Pengembangan Model Pembelajaran untuk Peningkatan Profesionalitas Guru. Surabaya : Kata Pena.

Ludi Wishnu Wardana, Ratna Setyani and Gleydis Harwida (2018). "The Implementation of the Two Stay TwoStray (Tsts) Learning Model and Co-Op Co-Op for the Improvement of Students' LearningOutcome in the Crafts and Entrepreneurship Subject" The First Journal International Research Conference on Economics and Business. 2018.

Nasution. 2008. Berbagai Pendekatan dalam Proses Belajar \& Mengajar. Cetakan keduabelas. Jakarta : Bumi Aksara.

Panpan Achmad Fadjri. (2000). Analisis kualitas sumber daya manusia menurut kota di Indonesi a”, Warta Demografi, 30 No.3: 34-39.

Sapriya. 2011. Pendidikan IPS Konsep dan Pembelajaran. Bandung: PT Remaja.

Slamet Widiyono (2007) yang berjudul "Partisipasi Masyarakat dalam Pelaksanaan Program Wajib Belajar Pendidikan Dasar 9 Tahun di Desa Sawangan dan Banyuroto, Sawangan Magelang".

Sudjana, Nana. 2009. Penilaian Hasil Proses Belajar Mengajar. Bandung: PT Remaja Rosdakarya

Sugiyono. 2010. Metode Penelitian Pendidikan Pendekatan Kuantitatif, kualitatif, dan R\&D. 
Bandung: Alfabeta.

Saroni, Muhammad. 2011. Manajemen Sekolah Kita Menjadi Pendidik Yang Kompeten. Ar-Ruzz Media, Yogyakarta

Susanto, Ahmad. (2014). Pengembangan Pembelajaran IPS di Sekolah Dasar. Jakarta: Prenadamedia Group

Tilaar, H.A.R. 2002. Pendidikan Kebudayaan dan Masyarakat Madani Indonesia. Bandung: Remaja Rosdakarya.

Todaro, M. P. dan S. C. Smith. 2003. Pembangunan Ekonomi di Dunia Ketiga. Jilid 1. Edisi Kedelapan. Jakarta: Erlangga.

Yong Wee Sek, Hepu Deng, Elspeth McKay and Minghui Qian, (2015). "Investigating the Impact of Learners' Learning Styles on the Acceptance of Open Learner Models for Information Sharing" Australasian Journal Conference on Information Systems. 2015. 